\title{
IMPLEMENTASI STRATEGI PEMBELAJARAN \\ KONTEKSTUAL DALAM PEMBENTUKAN KARAKTER PESERTA DIDIK DI SMP NEGERI 2 PINRANG
}

\author{
Henra Ibrahim \\ Email:henraibrahim@gmail.com \\ Guru SMPN 2 Pinrang
}

\begin{abstract}
This article discusses the implementation of students' character development strategies in learning Islamic Education in State Yunior High School 2 Pinrang. The purpose of this study is to describe the implementation of contextual learning strategies in the formation of character of students, to describe the implementation of contextual learning strategies in character building of students, and to describe the factors related to the strategy of developing contextual learning strategies to build the character in SMP 2 Pinrang. This type of research is descriptive qualitative using the naturalistic paradigm. The instruments of this research are: key instrument researchers and using interview, observation, and documentation guidelines. Informants interviewed were principals, vice principals, Islamic Education teachers, and students. The results of this study indicate that the implementation of contextual strategies was carried out through the learning process of Islamic Education by using methods in the 2013 curriculum combined with the use of information technology-based learning media. The implementation of the contextual impact strategy on improving the quality of learning in Islamic Education increases the appreciation of students for religious values, and fosters positive character for students. Implementation of contextual strategies by several factors, namely: existing infrastructure and infrastructure, competencies and qualifications of academic teachers, active teachers in teacher discussion activities, and the implementation of the 2013 curriculum related to contextual strategies, literacy, conversation, and the use of information technology-based media.
\end{abstract}

Keywords: Contextual, Character, Islamic Education, Information Technology 


\begin{abstract}
ABSTRAK
Artikel ini membahas implementasi strategi kontekstual dalam pembentukan karakter peserta didik pada pembelajaran Pendidikan Agama Islam di SMP Negeri 2 Pinrang. Tujuan penelitian ini adalah untuk mendeskripsikan implementasi strategi pembelajaran kontekstual dalam pembentukan karakter peserta didik, mendeskripsikan dampak implementasi strategi pembelajaran kontekstual dalam pembentukan karakter peserta didik, dan untuk mendeskripsikan faktor yang mempengaruhi implementasi strategi pembelajaran kontekstual dalam pembentukan karakter peserta didik di SMP Negeri 2 Pinrang. Jenis penelitian ini adalah deskriptif kualitatif dengan menggunakan paradigma naturalistis. Instrumen penelitian ini adalah: peneliti sebagai instrumen kunci dan menggunakan pedoman wawancara, observasi, dan dokumentasi. Informan yang diwawancara adalah kepala sekolah, wakil kepala sekolah, guru Pendidikan Agama Islam, dan peserta didik. Hasil penelitian ini menunjukkan bahwa implementasi strategi kontekstual terlaksana melalui proses pembelajaran Pendidikan Agama Islam dengan menggunakan metode-metode dalam kurikulum 2013 yang dipadukan dengan penggunaan media pembelajaran berbasis teknologi informasi. Implementasi strategi kontekstual berdampak pada peningkatan kualitas pembelajaran Pendidikan Agama Islam, meningkatkan penghayatan peserta didik terhadap nilai-nilai agama, serta menumbuhkan karakter positif kepada peserta didik. Pelaksanaan strategi kontekstual dipengaruhi oleh beberapa faktor, yaitu: sarana dan prasarana yang telah ada, kompetensi dan kualifikasi akademik guru, keaktifan guru dalam kegiatan musyawarah guru, dan diimplementasikannya kurikulum 2013 yang akomodatif terhadap strategi kontekstual, literasi, penguatan pendidikan karakter, dan penggunaan media berbasis teknologi informasi.
\end{abstract}

Kata Kunci: Kontekstual, Karakter, Pendidikan Agama Islam, Teknologi Informasi

\title{
PENDAHULUAN
}

\section{Latar Belakang}

Sistem pembelajaran klasik yang berbasis tekstual dan menggunakan metode pembelajaran konvensional dianggap kurang relevan lagi dengan kemajuan sistem pendidikan saat ini. Strategi pembelajaran tekstual menjadi praktik paling banyak dilakukan guru dalam menyampaikan materi 
pembelajaran. Metode yang digunakan pun masih bersifat konvensional seperti metode ceramah, tanya jawab, sistem hafalan dan praktik terbatas. Metode ini tidak hanya membosankan peserta didik dalam proses pembelajaran, tetapi juga berdampak pada lemahnya peran aktif peserta didik dalam menemukan, memahami, dan mengaitkan masalah dengan materi pembelajaran.

Kritik terhadap sistem pembelajaran klasik dalam dunia pendidikan dan pembelajaran memantik lahirnya sistem dan strategi pembelajaran yang mengatasi metode-metode sebelumnya. Strategi pembelajaran kontekstual atau populer disebut contextual teaching and learning (CTL) merupakan bagian dari tawaran alternatif dalam mengatasi persoalan klasik dalam proses pembelajaran. CTL menawarkan strategi berbeda dalam proses pembelajaran melalui koneksitas antara materi pembelajaran dengan realitas kehidupan peserta didik. Praktik CTL mengisyaratkan proses pembelajaran yang lebih aktif, kritis, kongkret, dan dialektis terhadap realitas sosial. CTL mengandung tujuh komponen penting, yakni: Konstruktivisme, Inquiry, Questioning, Learning Community, Modelling, Reflection, dan Authentic Assessment. Strategi CTL ini dapat diaplikasikan ke dalam Pendidikan Agama Islam dengan menyesuaikan berbagai materi dengan strategi-strategi praksis di dalam kelas. CTL kemudian dapat ditransformasi oleh seorang guru sesuai dengan karakter materi pembelajaran yang akan diajarkan kepada peserta didik.

Penggunaan strategi harus dipadukan dengan penggunaan media, terutama media berbasis teknologi informasi dalam proses pembelajaran. Hal itu bertujuan, selain untuk meningkatkan motivasi dan minat belajar, diharapkan pula menjadikan pembelajaran Pendidikan Agama Islam lebih bermakna bagi peserta didik. Misalnya, peserta didik mempelajari nilai-nilai karakter secara teori tetapi tidak mampu memaknai dan menghayati nilai-nilai tersebut. Dengan demikian, melalui strategi pembelajaran kontekstual yang diterapkan berupaya memberikan pemaknaan yang lebih realistis terhadap nilai-nilai karakter yang dipelajari secara teoretis.

Program penguatan pendidikan karakter menjadi salah satu program prioritas yang saat ini menjadi perhatian pemerintah mengingat perubahan sosial yang sangat dinamis yang dikhawatirkan berdampak terhadap perilaku peserta didik. Untuk itu, pendidikan karakter dalam dunia pendidikan dan pembelajaran perlu diperkuat dengan berbagai strategi. Proses pengintegrasian ini telah dilakukan secara baik di beberapa sekolah sasaran kurikulum 2013 termasuk di SMP Negeri 2 Pinrang. Pada studi pendahuluan yang telah dilakukan, strategi kontekstual telah diimplementasikan dalam proses pembelajaran di SMP Negeri 2 Pinrang untuk menanamkan nilai-nilai karakter 
kepada peserta didik. Bahkan yang menarik karena dalam proses pembelajaran Pendidikan Agama Islam telah diterapkan media berbasis teknologi informasi.

Pada sisi lain, karakter peserta didik yang ditumbuhkan melalui proses pembelajaran di SMP Negeri 2 Pinrang terefleksi dalam perilaku peserta didik di luar kelas. Dari pengamatan yang telah dilakukan pada observasi pendahuluan, peserta didik di SMP Negeri 2 Pinrang berperilaku sopan misalnya jika bertemu dengan guru mereka menyapa dan bersalaman bahkan sambil mencium tangan gurunya. Peserta didik juga rajin shalat duha dan shalat zuhur berjamaah di Mushollah, adanya kebiasaan menyumbang, adanya karyakarya peserta didik berupa karya literasi yang bertema pendidikan karakter. Kondisi ini merupakan fakta-fakta yang dapat dijadikan sebagai bahan untuk merefleksikan implementasi pendidikan karakter di SMP Negeri 2 Pinrang.

Penerapan strategi kontekstual memberikan nuansa baru dalam proses pembelajaran Pendidikan Agama Islam, sehingga makna-makna dari materi yang diajarkan khususnya berkaitan dengan penanaman nilai-nilai moral kepada peserta didik lebih efektif dilakukan. Meskipun strategi kontekstual secara eksplisit diterapkan dalam strategi pembelajaran Pendidikan Agama Islam di SMP Negeri 2 Pinrang, namun belum diketahui dampaknya terhadap pembentukan nilai-nilai karakter peserta didik. Oleh karena itulah, penulis tertarik mengangkat judul penelitian yang berkaitan dengan strategi pembelajaran kontekstual hubungannya dengan pembentukan karakter peserta didik dalam pembelajaran Pendidikan Agama Islam.

\section{Rumusan Masalah}

Berdasarkan Fokus Penelitian dan Deskripsi Fokus di atas, maka rumusan masalah dalam penelitian ini adalah:

1. Bagaimana implementasi strategi pembelajaran kontekstual dalam pembentukan karakter peserta didik di SMP Negeri 2 Pinrang?

2. Bagaimana dampak implementasi strategi pembelajaran kontekstual dalam pembentukan karakter peserta didik di SMP Negeri 2 Pinrang?

3. Faktor apakah yang menentukan implementasi strategi pembelajaran kontekstual dalam pembentukan karakter peserta didik di SMP Negeri 2 Pinrang?

\section{Telaah Pustaka}

\section{Penelitian yang Relevan}

Agar penelitian ini memiliki pijakan yang kuat dalam kerangka kajian ilmiah dan memiliki kedudukan yang tepat dalam sebuah kajian akademik dan 
penelitian, maka peneliti melakukan telaah terhadap hasil-hasil penelitian terdahulu yang relevan dengan penelitian ini. Hasil-hasil penelitian tersebut dijelaskan sebagai berikut: Pertama, Tesis ditulis oleh Suaeba, mahasiswa Program Pascasarjana UIN Alauddin Makassar Tahun 2012 dengan judul "Implementasi Pendekatan Contextual Teaching and Learning (CTL) pada Pembelajaran Pendidikan Agama Islam di SMP Negeri 1 Parangloe Kabupaten Gowa”. Penelitian ini memfokuskan pada tiga permasalahan, yaitu: Bagaimana implementasi CTL dalam pembelajaran di SMP Negeri 1 Parangloe Kab. Gowa, Apa kendala yang dihadapi dalam proses pelaksanaan pembelajaran dengan metode CTL, serta Bagaimana implikasi penerapan metode CTL dalam pembelajaran Pendidikan Agama Islam di SMP Negeri 1 Parangloe Kabupaten Gowa.

Kedua, Tesis mahasiswa Program Pascasarjana IAIN Raden Intan, Lampung, 2016, atas nama Lilis Yuliana, berjudul "Implementasi Pendekatan Pembelajaran Contextual Teaching and Learning (CTL) dalam Meningkatkan Hasil Belajar Siswa pada Mata Pelajaran Fikih di MTs Alkhairiyah Kaliawi”. Penelitian ini berangkat dari permasalahan rendahnya hasil belajar peserta didik pada mata pelajaran Fikih di MTs Al Khairiyah Kaliawi-Tanjung Karang Pusat karena disebabkan oleh pembelajaran yang tekstual dan menggunakan metode ceramah, sehingga peserta didik kesulitan dalam mengaitkan materi pembelajaran dengan realitas kehidupan sehari-hari khususnya dalam persoalan fikih.

Ketiga, Tesis berjudul "Strategi Guru Pendidikan Agama Islam (PAI) dalam Menanamkan Nilai-nilai Karakter pada Siswa”, ditulis oleh Afifah, mahasiswa Program Pascasarjana UIN Maulana Malik Ibrahim, Malang, Tahun 2016. Penelitian ini bertujuan melihat bagaimana implementasi pendidikan karakter yang telah dicanangkan oleh pemerintah. Nilai-nilai karakter apa yang ditanamkan oleh guru dalam proses pembelajaran. Selain itu, penelitian yang dilakukan di SDI Raudlatul Jannah Sidoarjo dan SDIT Ghilmani Surabaya ini, bermaksud pula mendeskripsikan strategi guru Pendidikan Agama Islam pada kedua sekolah tempat penelitian dalam menanamkan nilai-nilai karakter kepada peserta didiknya. Dengan menggunakan pendekatan kualitatif, penelitian ini menyimpulkan bahwa strategi guru dalam menyampaikan dan menanamkan nilai-nilai karakter kepada peserta didik adalah dengan mengaplikasikan peran personal guru sebagai pendidik, pengajar, pengembang kurikulum, pembaharu, model keteladanan, dan mengintegrasikan nilai-nilai karakter ke dalam semua mata pelajaran, praktik sehari-hari, program sekolah, dan kolaborasi guru dan orang tua peserta didik. 
Keempat, Tesis yang ditulis oleh Muhammad Wahyudi, Mahasiswa Program Pascasarjana UIN Maulana Malik Ibrahim Malang, 2016, berjudul "Implementasi Pembelajaran Pendidikan Agama Islam (PAI) dalam Pembentukan Karakter Religius dan Sikap Kepedulian Sosial Siswa di SMK Negeri 1 Kota Batu”. Latar belakang tesis ini berkaitan dengan urgensi penerapan pendidikan karakter dalam proses pembelajaran. Berbagai metode pembelajaran yang efisien diharapkan menjadi alternatif solutif dalam menanamkan nilai-nilai karakter pada peserta didik. Penelitian yang dilakukan di SMK 1 Kota Batu menggunakan pendekatan penelitian kualitatif dengan fokus pada dua nilai karakter yang diteliti yaitu nilai karakter tentang religius dan nilai karakter tentang peduli sosial. Tujuan penelitiannya untuk mendeskripsikan nilai karakter religius dan peduli sosial yang diimplementasikan oleh peserta didik di SMK 1 Kota Batu, mendeskripsikan implementasi pembelajaran dalam pembentukan karakter, dan faktor pendukung dan penghambat dalam penerapan pendidikan karakter di SMK 1 Kota Batu. Hasil penelitian Wahyudi menunjukkan bahwa karakter religius yang ditampilkan oleh peserta didik di SMK 1 Kota Batu adalah para peserta didik memiliki keimanan yang kuat, ketakwaan, akidah kuat, dan berpegang teguh pada syariat Islam. Sementara untuk nilai-nilai yang berkaitan dengan peduli sosial ditunjukkan dengan sikap pengabdian, tolong menolong, kekeluargaan, kepedulian, kerjasama, dan toleransi. Sementara itu, untuk implementasi penanaman nilai-nilai karakter dalam pembelajaran di SMK 1 Kota Batu dilakukan dengan mulai melakukan perencanaan pembelajaran berupa silabus, sosialisasi, RPP pembelajaran PAI, dan melalui kegiatan intra sekolah maupun ekstrakurikuler sekolah, serta pelaksanaan evaluasi yang autentik. Pada bagian lain, tesis ini menunjukkan pula faktor-faktor pendukung dan penghambat pembelajaran karakter. Faktor pendukungnya adalah karena ketersediaan sarana dan prasarana seperti keberadaan Mushollah, perpustakaan Islami, pengeras suara, dan kebiasaan bersalaman antara guru dan peserta didik, tersedianya AlQuran, adanya alat bantu belajar seperti LCD di setiap kelas. Sedangkan untuk faktor penghambatnya adalah pergaulan peserta didik khususnya di luar sekolah, latar belakang kehidupan peserta didik yang berbeda-beda, dan faktor lingkungan yang kurang mendukung.

Penelitian ini memiliki beberapa kesamaan dengan penelitian sebelumnya, khususnya berkaitan dengan implementasi dan kendala strategi pembelajaran kontekstual dalam proses pembelajaran. Namun memiliki penekanan berbeda terutama dalam menggali data terkait dengan implementasi strategi kontekstual dalam proses pembelajaran. Salah satu sisi yang menjadi perhatian dalam 
penelitian ini adalah berkaitan dengan integrasi teknologi informasi dalam implementasi strategi pembelajaran kontekstual di SMP Negeri 2 Pinrang. Dengan demikian, penelitian ini akan memperkaya hasil penelitian sebelumnya pada wilayah penelitian lain yang memiliki karakteristik berbeda dari wilayah sebelumnya.

\section{Landasan Teori}

\section{Strategi Pembelajaran Kontekstual}

\section{a. Hakikat Pembelajaran Kontekstual}

Pembelajaran kontekstual atau dikenal dengan istilah Contextual Teaching and Learning (CTL) sesungguhnya adalah gagasan yang sejak awal berpijak pada konsep dasar yang disampaikan oleh Jhon Dewey sejak 1916. Dewey memandang bahwa sangat penting mengaitkan atau mengoneksikan antara kurikulum dan metodologi pengajaran dengan pengalaman peserta didik. Elaine B. Jhonson, menjelaskan bahwa pembelajaran kontekstual adalah sistem pembelajaran yang memandang bahwa makna muncul dari koneksi antara isi dan konteks. Semakin luas seorang peserta didik menemukan konteks dari sebuah pengetahuan, maka semakin bermaknalah isi pengetahuan yang dimiliki oleh seorang peserta didik. Peserta didik yang mampu memahami makna dari pengetahuan dan keterampilan akan menuntunnya dalam mengusai pengetahuan dan keterampilan itu.

\section{Jenis dan Pendekatan Penelitian}

Penelitian ini merupakan jenis penelitian deskriptif dengan menggunakan pendekatan kualitatif. Penelitian kualitatif sendiri memiliki beberapa karakteristik yang membedakannya dengan penelitian lainnya, di antaranya adalah tingkat kealamiahan sebuah penelitian. Penelitian kualitatif menggali informasi dan data secara alamiah melalui pengamatan langsung dan berkomunikasi dengan orang-orang atau objek yang diteliti di wilayah tertentu, bukan dikondisikan dengan kehendak peneliti. Artinya peneliti harus bergumul dengan realitas objek penelitian.

\section{Paradigma Penelitian}

Paradigma penelitian ini adalah merujuk pada naturalistic paradigma yang melihat realitas apa adanya. Dengan kata lain, hasil penelitian dideskripsikan sebagaimana mestinya tanpa melakukan intervensi. Penerapan strategi kontekstual dalam pembelajaran PAI di SMP Negeri 2 Pinrang dijadikan 
sebagai realitas alamiah yang dikaji relevansinya dengan penanaman nilai-nilai karakter peserta didik.

\section{Sumber Data}

Data utama dalam penelitian ini bersumber dari informan yang berkaitan langsung dengan tema penelitian. Adapun informan yang dimintai informasi terkait dengan tema penelitian ini adalah: Guru Pendidikan Agama Islam di SMP Negeri 2 Pinrang, Kepala SMP Negeri 2 Pinrang, Wakil Kepala sekolah bidang kurikulum dan pengajaran, peserta didik, dan tata usaha.

Sementara data pendukung berupa dokumen tertulis, foto, dan video berkaitan dengan penerapan strategi pembelajaran kontekstual dalam kurikulum yang digunakan oleh guru dan sekolah. Data pendukung dapat pula berupa keterangan-keterangan lainnya yang menggambarkan pelaksanaan pembelajaran pada lokasi penelitian yang memiliki relevansi terhadap tema penelitian.

\section{Waktu dan Lokasi Penelitian}

Penelitian ini dilaksanakan pada bulan Juni-Agustus 2018 yang berlokasi di SMP Negeri 2 Pinrang, Jl. Benteng, No. 39, Kecamatan Paleteang, Kabupaten Pinrang.

\section{Teknik Pengumpulan Data}

Untuk memperoleh data yang diperlukan dalam penelitian ini, maka dibutuhkan beberapa teknik pengambilan data. Teknik yang dipilih tentunya harus relevan dengan pendekatan kualitatif yang digunakan dalam penelitian ini. Dengan demikian beberapa teknik yang digunakan dalam penelitian ini adalah observasi, wawancara, dan dokumentasi.

\section{Instrumen Penelitian}

Untuk itu, peneliti adalah instrumen kunci selain instrumen berikut ini:

1). Pedoman observasi

2). Pedoman wawancara

3). Pedoman Dokumentasi

\section{Tahapan Pengumpulan Data}

Tahapan pengumpulan data merupakan proses untuk membatasi penelitian, mengumpulkan informasi melalui wawancara dan observasi. Tahapan pelaksanaan pengumpulan data dilakukan melalui beberapa tahapan penting yang antara satu dan lainnya saling berkaitan. 
Pertama, penentuan lokasi atau informan yang ditentukan secara purpossive atau dengan pertimbangan tertentu. Kedua, menentukan jenis data yang dicari dalam proses penelitian.

\section{Teknik Pengolahan dan Analisis Data}

Teknik yang digunakan dalam melakukan analisis data merujuk pada teknik yang dikemukakan oleh Miles dan Huberman. Sebagaimana dikutip dalam Sugiyono, Miles dan Huberman, menjelaskan bahwa dalam penelitian kualitatif proses analisis data berlangsung secara interaktif dan berlangsung secara terus menerus hingga data jenuh dan sudah dianggap kredibel untuk membuat sebuah kesimpulan. Secara bertahap analisis data dilakukan mulai dari data reduction, data display, dan conclusion/drawing/verification.

\section{Teknik Pengujian dan Keabsahan Data}

Data temuan penelitian perlu diproses lebih cermat, sehingga data temuan benar-benar tidak menyimpang dari kebenaran objek penelitian. Untuk itu, dilakukan teknik pengujian keabsahan data melalui teknik ketekunan/keajegan pengamatan dan triangulasi.

\section{PEMBAHASAN}

\section{Implementasi Strategi Pembelajaran Kontekstual dalam Membentuk Karakter Peserta Didik di SMP Negeri 2 Pinrang}

Dari langkah-langkah pembelajaran ini dapat disimpulkan bahwa metode pembelajaran yang dilaksanakan oleh guru sejalan dengan konsep strategi pembelajaran CTL. Adapun komponen CTL secara eksplisit dapat dilihat dalam RPP yaitu: (1) komponen konstruktivisme terintegrasi dalam proses pemberian stimulus kepada peserta didik untuk mengonstruksi sendiri pengetahuannya berdasarkan pengalaman dan fakta-fakta yang diamati oleh peserta didik; (2) komponen inkuiri berada pada saat guru mengarahkan peserta didik mengeksplorasi materi pembelajaran; (3) komponen bertanya terletak pada tahap peserta didik mengajukan pertanyaan dari tayangan; (4) komponen masyarakat belajar diakomodasi pada proses diskusi yang dilakukan peserta didik; (5) komponen modeling termuat dalam tahapan peserta didik mengerjakan LK yang berisi petunjuk cara mengerjakan LK dan bimbingan guru dalam mengerjakan LK; (6) komponen refleksi dilaksanakan pada tahap penutup di mana guru memberikan penguatan dan memandu peserta didik mengevaluasi proses pembelajaran; dan (7) komponen penilaian termaut dalam lembar evaluasi yang ada pada lampiran RPP. Dengan demikian, pembelajaran 
Pendidikan Agama Islam telah mengimplementasikan strategi kontekstual secara nyata.

\section{Dampak Implementasi Strategi Pembelajaran Kontekstual dalam Membentuk Karakter Peserta Didik di SMP Negeri 2 Pinrang.}

Dampak pembelajaran Pendidikan Agama Islam dengan pendekatan kontekstual berbasis teknologi informasi tidak hanya meningkatkan kualitas pembelajaran Pendidikan Agama Islam dari sisi kognitifnya saja, tetapi juga mengubah kesan pembelajaran agama yang cenderung konvensional, membosankan bagi peserta didik, serta dampak yang paling luas adalah bahwa pembelajaran Pendidikan Agama Islam memiliki kesan pembelajaran yang lebih bermakna dan dapat mempengaruhi karakter peserta didik.

Faktor yang Menentukan Implementasi Strategi Pembelajaran Kontekstual dalam Membentuk Karakter Peserta Didik di SMP Negeri 2 Pinrang.

Implementasi strategi pembelajaran kontekstual dalam upaya penguatan pendidikan karakter dipengaruhi oleh berbagai faktor terutama faktor pendukung dalam proses pembelajaran dan pendidikan secara umum di dalam lingkungan sekolah. Selain itu, faktor yang menentukan terselenggaranya pembelajaran berbasis kontekstual juga turut dipengaruhi oleh kompetensi dan latar belakang akademik yang dimiliki oleh guru Pendidikan Agama Islam yang ada di SMP Negeri 2 Pinrang. Selain itu, kendala lain khususnya dalam kemampuan guru yang tidak merata dalam mengaplikasikan strategi pembelajaran kontekstual jika dipadukan dengan pemanfaatan media pembelajaran berbasis teknologi informasi.

Pertama, guru menyampaikan materi pembelajaran dimulai dengan memberikan stimulus kepada peserta didik melalui penayangan media berbasis video, gambar, foto, audio, bahkan film yang relevan dengan materi pembelajaran. Kedua, setelah peserta didik menyimak berbagai gambar, video, film, atau menyimak audio, mereka diberikan lembar kerja yang akan dijawab, diberi komentar, respons, dan tanggapan. Ketiga, peserta didik melakukan eksplorasi terhadap berbagai sumber dan referensi yang berkaitan dengan permasalahan yang telah dirumuskan. Keempat, penarikan kesimpulan dari data yang telah ditemukan oleh peserta didik sebagai bahan yang akan dipresentasikan di depan kelas. Kelima, presentasi hasil diskusi kelompok dilakukan setelah peserta didik merumuskan kesimpulan atau memberikan jawaban terhadap permasalahan yang telah dirumuskan. 


\section{SIMPULAN}

Melalui deskripsi dan pembahasan hasil penelitian tentang implementasi strategi kontekstual dalam meningkatkan karakter peserta didik di SMP Negeri 2 Pinrang, maka dirumuskan beberapa simpulan sebagai berikut:

1. Implementasi strategi kontekstual dalam proses pembelajaran Pendidikan Agama Islam di SMP Negeri 2 Pinrang tercermin dari langkah-langkah pembelajaran di dalam kelas yang menunjukkan bahwa komponenkomponen strategi kontekstual terlaksana.

2. Dampak implementasi strategi pembelajaran kontekstual dalam proses pembelajaran Pendidikan Agama Islam mengarah pada peningkatan motivasi belajar, antusiasme belajar, keaktifan peserta didik, penghayatan peserta didik terhadap materi pembelajaran, dan pembentukan karakter peserta didik melalui pembelajaran materi Pendidikan Agama Islam yang relevan.

3. Faktor-faktor yang menentukan implementasi strategi kontekstual dalam proses pembelajaran Pendidikan Agama Islam untuk membentuk karakter peserta didik dipengaruhi oleh beberapa aspek, baik yang mendukung maupun yang masih menjadi kendala.

\section{A. Implikasi}

Berdasarkan analisis dan simpulan yang telah dipaparkan, maka berikut ini dikemukakan beberapa implikasi dari penelitian ini:

1. Strategi kontekstual dalam proses pembelajaran Pendidikan Agama Islam relevan untuk meningkatkan pemahaman, penghayatan, dan pengamalan nilai-nilai agama.

2. Agar strategi kontekstual dapat berjalan dengan efektif dalam proses pembelajaran, maka perlu dipadukan dengan media pembelajaran berbasis teknologi informasi.

3. Penguatan implementasi kurikulum 2013 perlu dilakukan karena kurikulum ini memuat berbagai metode pembelajaran yang telah mengakomodasi strategi pembelajaran kontekstual. 
84 | Henra Ibrahim

\section{DAFTAR PUSTAKA}

Budiningsih, Asri. Belajar dan Pembelajaran. Jakarta: Rineka Cipta, 2005.

Johnson, Elaine B. Contextual Teaching and Learning, Terj. Ibnu Setiawan. Bandung: Kaifa Learning, 2011.

Lickona, Thomas. Mendidik untuk Membentuk Karakter. Diterjemahkan oleh Juma Abdu Wamaungo. Jakarta: Bumi Aksara, 2012.

Ludjito, Ahmad. Pendidikan Sebagai Subsistem dan Implementasinya dalam Pendidikan Nasional. Yogyakarta: Pustaka Pelajar, 1998.

Muhaimin. Paradigma Pendidikan Islam; Upaya Mengefektifkan Pendidikan Islam di Sekolah. Bandung: Remja Rosda Karya, 2012.

—. Rekonstruksi Pendidikan Islam. Jakarta: Raja Grafindo Persada, 2009.

Mulyasa, H.E. Manajemen Pendidikan Karakter. Jakarta: Bumi Aksara, 2016.

Nurhadi. Pembelajaran Kontekstual dan Penerapannya Dalam KBK. Malang: UM Press, 2014.

Rusman. Model-Model Pembelajaran Mengembangkan Profesionalisme Guru. Jakarta: PT. Raja Grafindo Persada, 2011.

Sanjaya, Wina. Strategi Pembelajaran Berorientasi Standar Proses Pendidikan. Jakarta: Kencana Prenada Media Group, 2016. 